\title{
ETHICS OF DWELLING: \\ EARLY CHRISTIAN PRINCIPLES OF THE CITY LIFE AND URBAN TRANSFORMATION
}

\author{
A B S T R A C T
}

The work (paper) focuses on a particular issue regarding ethics developing in early Christian time and its influence on the process of transformation of Roman urban life, habits, functions, and architectural practice in the late fifth century and after.

Complexity of this issue derives from the fact that the early Christian monastic ideals, which had been rapidly developed in the first centuries of the new era, substantially influenced the formation of everyday living ethical principles.

Consequently, these new principles changed existing dwelling habits, particularly in the field of public life, demanding a new form of behavior from the Christian citizens. This process also influenced the idealistic view on what the concept of a Christian city can be, and how the new form of ethical life reflects on new urban and architectural structures. 
In the first few centuries of the Christian era, an idea concerning particular ethical model developed, by which Christians were asked to behave within everyday private and public life. This idea has been developing parallel with the general establishment of Christian theology, and particularly with the notion by which every Christian should follow the archetypal model of virtue, the life of Christ and the saints.

The particular interest of our topic is the actual belief that habits and life in cities should be modeled by this notion of virtue, by which the Christian citizens would differentiate from their pagan neighbors. In that context the early Christian writers have been identifying particular Roman public buildings and their function with the sinful pagan behavior and life. Cities become a battlefield between new rising religion and the pagan practice of public events, through which, as Christians believed, pagans were exposing blasphemous enjoinments. However, in their critic Christians also focused on the practice of luxurious dwelling, as a source of many sinful behaviors.

At the beginning of the third century Tertullian condemned through his writings not only the pagan idolatry hosted by temples and shrines, but also, and that very strongly, all other public and private urban functions such as rich residences and houses, baths and tenements, circuses and theaters. In his treatise De spectaculis, Tertullian defines the model of virtue and behavior of a Christian citizen: Ye servants of God, about to draw near to God, that you may make solemn consecration of yourselves to Him, seek well to understand the condition of faith, the reason of the Truth, the laws of Christian discipline, which forbid among other sins of the world, the pleasures of the public shows. ${ }^{1}$ In his opinion all Roman public shows are by their origin founded in pagan religion, celebrating idols and provoking passionate excitements hostile to Christian spirituality. Tertullian emphasizes that even our very dwelling places are not altogether free from idols which are tracing their way to the human hearts trough luxury and immodesty in decoration, food, and adornment of the body. ${ }^{2}$

We should emphasize that such an early Christian standpoint has its counterpart in some idealistic positions developed in antiquity, regarding the relationship of the city and society, or architecture and the character of its inhabitants. For instance, in Plato's and later stoic writings, ethical values concerning life habits are identified with the material structure of a city or a house, establishing a new form of fundamental ethic values. These examples are pointing out a long philosophic tradition which gives architecture the power to manifest important ethical issues. 
Plato's visions are founded on the idea of equality between the level of moral and ethical values of the citizens and correctness of the functional, firm, and regular building structure. Social values are reflecting on the building values, and vice versa. Plato even explains the fall of cities as the consequence of the corruptness of their citizens, as well as extreme social inequality. ${ }^{3}$

On the other hand, Plato's attitude towards materialization and the shape of his ideal visions of urban structure points out a few important issues for our topic.

In the Laws, Plato emphasizes that the shape of an ideal city should be the one of a circle. Moreover, he goes into a detailed description of a desirable arrangement of cities: The private houses ought to be so arranged from the first that the whole city may be one wall, having all the houses capable of defence by reason of their uniformity and equality towards the streets. The form of the city being that of a single dwelling will have an agreeable aspect, and being easily guarded will be infinitely better for security. ${ }^{4}$

Careful reading of this section identifies two main reasons for this Platonic ideal request for arranging the city. The first refers to the easier establishment of defence and security, which is one of the main components of beauty. The second relates to the amenity provided by equality of buildings in the eye of the beholder, which obviously stems from Plato's view that the equality of the houses actually underlines the equality of citizens, representing therefore a desirable classic ideal of democracy.

On the other hand, the visual equality of houses and the subsequent pleasantness to the eye are a manifestation of higher order of harmony and reflect, to a greater extent, spiritual harmony, as opposed to the diversity of natural forms, which could be interpreted as a manifestation of a lower degree of harmony.

Actually, Plato's reflection on ideal city comes from his general position by which the State [city] is to be so fashioned that the influence of its organisation may create in the souls of its individual citizens that habit and proportion which is profitable for eternity. ${ }^{5}$ It marks his essential statement that all political, social, and cultural values should be subordinated to ethics.

Later, in Roman Stoic writings one can find similar reflections equalizing ethical with the spiritual quality of dwelling, and the aesthetic properties of architecture. That way, for example, Seneca builds a complex vision unifying moral qualities and character of the inhabitant with spiritual quality of life and the tranquil atmosphere of a modest house architecture. ${ }^{6}$ 
Similar to these ideas underlining the importance of Christian ethical categories when judging the value of a city, the fourth century church father St. John Chrysostom teaches that the dignity of the city lies in the virtue and piety of its inhabitants; this is a city's dignity, and ornament, and defence. ${ }^{7}$ The beauty of spiritual values and chastity is now the foundation of the quality of dwelling within the Christian community. However, by its eternal virtue, Christian religion has a power to transform a corrupted and devastated city into the marvellous settlement, as emphasized by Sulpitius Severus in his comment on the building activities undertaken by the Empress Helena in Jerusalem. ${ }^{8}$ Such activities have been in the first place events of spiritual lifting, rather than the exhibition of material wealth and superficial glorification of human vanity.

Turning our discussion back to St. Chrysostom, we should emphasize that in his writings there is an equal standpoint concerning the practice of Christian ethical norms on the level of public behaviour in the city, as well as in the habits of individual dwelling. For instance, in his comments on the Biblical story of Abraham's hospitality, the ethical behaviour and host's virtuous character, are overcoming the modesty of his house. ${ }^{9}$ This way Abraham was building tabernacles in heaven that would never get corrupted.

Nevertheless, St. Chrysostom was also entirely in Tertullian's position when it comes to condemnation of pagan urban habits. Commenting the decree of Emperor Theodosius I, closing down orchestra, hippodrome, baths, and many other public buildings in the city of Antioch, St. Chrysostom was proclaiming them useless and opposite to the real essential values of ethical habits that each Christian citizen should have. His notion that by this Emperor's proclamation our city has become all at once a monastery has a particular importance for our research. ${ }^{10}$

By identifying the purified city of Antioch with a monastery, St. Chrysostom actually brought up a Christian ethical ideal integrating the contemplative spirit and the community life. It seems that this idealistic position was from a particular value for the early Church fathers. In his Panegyric on St. Basil, Gregory of Nazianzen glorifies exactly that achievement of the one of the first promoters of monastic life. Talking about St. Basil's Christian virtues and achievements, Gregory emphasises the saint's regulations by which he won the real practice of virginity, turning inward the view of beauty, from the visible into invisible... Moreover he reconciled most excellently and united the solitary and the community life... he brought them together and united them, in order that the contemplative spirit might not be cut off from society, nor the active 
life be uninfluenced by the contemplative, but that, like sea and land, by an interchange of their several gifts, they might unite in promoting the one object, the glory of God. ${ }^{11}$

The city actually becomes the place where the ideal of ethical dwelling has been promoted, as in its archetypal image, the monastery, where all virtue has been inhabited. By this, the monastery and the monastic life can be interpreted as ethical core of a city and of the life within it. In that context Gregory named the new monastery and hospital established by St. Basil the new city, the storehouse of piety, the common treasury of wealthy, in which the superfluities of their wealth, aye, and even their necessaries, are stored, in consequence of his exhortations, freed from the power of moth, no longer gladdening the eyes of the thief, and escaping both the emulation of envy, and the corruption of time... ${ }^{12}$ In fact, Gregory interpreted the monastery as eternal place of Christian dwelling, an ethical city founded on the example of Christ's life and deeds.

It seems that in these early centuries of Christianity, example of St. Basil's ideal was not the only one. In his writings, Palladius, Bishop of Helenopolis describes a monastic settlement at the mountain of Nitria in Ethiopia, where a harmonious community has been living, composed from monks and commons gathering and working according to the Christian ethical principles: In this mountain is a great church... Adjoining the church is a house in which the strangers who arrive there may lodge, and if any man wished to work there one year, or two, or until he departed of his own accord he may do so... All these people worked at the weaving of linen with their hands, and there was no needy man there. Now when the evening cometh thou must rise up to hear the praises, and the Psalms, and the prayers which are sent up to Christ by the people from the monasteries which are there, and a man might imagine, his mind being exalted, that he was in the Paradise of Eden. ${ }^{13}$

However, it seems that the analyzed examples are emphasizing a particular ideal by which the perfect Christian society, dwelling in the cities and monasteries, should actually incline to mirror a vision of a new heavenly settlement. The essential ideal of ethical dwelling is not related to the earthly world, although the Christians are using it to achieve the spiritual transformation into the eternal life.

In that sense, after instructing his Christian brothers and sisters to avoid the pagan spectacles and way of living, Tertullian was emphasizing the reality of the forthcoming kingdom of Christ and the rise of the New Jerusalem. Although not clear about the possibility of achieving the ideal vision of Christian society 
in this world, Tertullian was using the notion of the New Jerusalem as the model of ethical life within the spiritually perfectly shaped society. ${ }^{14}$

A similar notion can be seen in St. Chrysostom's statement that after Emperor Theodosius cleaned the city of Antioch from all pagan sinful habits it became metropolis, not in the earth, but in heaven, particularly emphasising that Christians should seek the heavenly city build by God. ${ }^{15}$ However, if the Saint equalized the ethically purified city with monastery, as we have seen in the previous analysis, is it possible that by this notion a monastery is a form of heavenly city on earth, or at least its materialized vision?

At this point maybe we should recall the very definition of what Heavenly City is, by the words of early fathers of the Church. In the writings of Gregory of Nazianzen the Jerusalem above was the object not of sight but of contemplation, wherein is our commonwealth, and whereto we are pressing on; whose citizen Christ is, and whose fellow - citizens are the assembly and church of the first born [innocents] who are written in heaven, and feast around its great Founder in contemplation of His glory, and take part in the endless festival; her mobility consisted in the preservation of the Image, and the perfect likeness to the Archetype, which is produced by reason and virtue and pure desire, ever more and more conforming, in things pertaining to God, to those truly initiated into the heavenly mysteries; and in knowing whence, and of what character, and to what end we came into being. ${ }^{16}$

Thus presented, the idea of the Heavenly City summarises all essential aspects of Christian beliefs and life goals. It also points out recognisable matrix of the monastic life through spiritual purification, and the unification of the earthly and heavenly liturgy as two manifestations of Gods eternal glory. In its very essence this is the core of Christian ethics, and dwelling within the City of Heavens is an ideal guiding all earthly activities.

However, there is always an open question regarding the ways of material manifestation of these spiritually elevated visions. In that context we should keep in mind that the Christian fathers do interpret physical structures of architecture in levels of meanings, and that they easily shift from earthly into spiritual categories. In one of the Early Christian Fathers, John Cassian, we can identify one of the early concepts of developing levels of meanings in an interpretation of architecture. He says that Jerusalem can be taken in four senses: historically, as the city of the Jews; allegorically, as the Church of Christ; anagogically, as the heavenly city of God which is the mother of as all; tropologically, as the soul of man, which is frequently subject to prise or blame from the Lord under this title. ${ }^{17}$ 
In that context, there is equivalence between ideas of earthly sacral buildings and the visions of spiritual buildings. Moreover, in the mediaeval texts there is a constant shift between metaphorical values of the Church as a community and the church as a building, being representing the body of Christ which can reflect in the ark of Noah as the image of salvation, which is again the heavenly Jerusalem, in other words the idea of monastery as a communion of Christians and the City of God.

By all this, it seems that the formation and spatial structure of mediaeval monasteries is deeply rooted in the allegoric interpretation of the Christian ideas concerning the idealistic vision of the heavenly or New Jerusalem. In some examples named as the City of God, versus the city of evil, the heavenly building has been constructed on the foundations of Christian virtues and spiritual illumination provided by the power of faith. Its citizens are physiologically united under the roof of the devotion to God, and hierarchically equalized by the strength of their unshakable love for Christ. Their bodies are the stones of the walls of the City of God. The strength of their faith provides the firmness of the divine structure. ${ }^{18}$

Again in one text of St John Chrysostom we can read that the Church is nothing else than a house built of the souls of us men. Besides the idea that this building is arranged in a hierarchical order of souls, each contributing according to its spiritual strength, the spatial morphology of it has been also given: we may see a multitude, forming generally the wide space and the whole extend of the circumference; for the body of large occupies the place of those stones of which the outer walls are built. ${ }^{19}$

Spiritual stones are materialized and presented as made of gold, silver and precious stones, as in the Biblical vision of the heavenly Jerusalem, and they are a metaphorical expression of the Christian virtue and faith. The indication of a circular shape of the city and the existence of the outer wall, a space arrangement similar to the Plato's ideal circular city, is from a particular interest in this vision.

Another early Christian text from the fourth century, the apocryphal Vision of Paul, shows that the previous description of the spiritual building of Christian faith was not an exemption, but a rule. Paul describes: ... and I entered and saw the City of Christ, and it was all of Gold, and twelve walls encircled it, and twelve interior towers, and each wall had between them single stadia in the circuit... And there were twelve gates in the circuit of the city, of great beauty, and four rivers which encircled it....And I saw in the midst of this city a great altar, very high... ${ }^{20}$ 
The importance of this description rises from the fact that it has been depicted in later manuscripts of the middle age. However, the spatial arrangement shown in the passage is very similar to a later eight century vision, where the throne of God is surrounded by seven crystal walls, depicting the cosmic structure of spheres. ${ }^{21}$

The important metaphor regarding the translation of the stones of the church from their earthly places to the heavenly building through the death of the flesh of monks and clerics comes out as a common place in mediaeval texts. ${ }^{22}$ It proves that the churches and monasteries have been regarded in their materiality and structure as an energetic matrix gathering the souls of Christians, on which essentially they relay, and therefore equal to the heavenly buildings. The named transition between the earthly and heavenly existence was, therefore, essentially very easy, however always related to the state of moral and ethical values of souls. Nevertheless, there is a feeling when reading the latest passage of Beda, that the souls (read Stones) are taking the same position in heavenly buildings, as they had in their earthly life.

It seems that the most developed ideas regarding our topic can be found in the work of Hugo of St. Victor. In his treatises De arca Noe mystica and De claustro animae Hugo interprets the material structure of the edifices as the formation of essential Christian value. ${ }^{23}$ In this context, the metaphorical comments on the square shape as the basic geometric form of the ark and the monastic courtyard is essential, because it links the physical structure with the moral and spiritual requirements of the Christian theology of salvation. Hugo's ideas prove that the medieval language of anagogical interpretation and reading is essential for our understanding of the link between the material structures of sacral buildings and their meanings. Reflecting on John Cassian's concept of meanings of a material structure, Hugo in a scholastic interpretation develops his system. ${ }^{24}$ It shows that there is actually a sign of equality between a physical structure and theological interpretation of Christian salvation.

However, in the mediaeval Christian literal tradition we can find examples of an explicit link between the material structure of a monastic complex and church within it, and the vision of the heavenly Jerusalem. In a few Serbian medieval texts regarding building of monasteries, there is a constant equivalence between terms monastery and city. More than that, these cities are interpreted as containing a path leading towards the heavenly Jerusalem to which they are similar. ${ }^{25}$ Actually, the path is the church building in the middle of the monastery which is usually in a circular shape. Interesting that 
the buildings containing monastic cells are usually named as palaces and they structure in a broader context of the orthodox monastic tradition do expose a city as architectural structures. (Not clear what you wanted to say in the last sentence of this paragraph)

All descriptions indicate that the vision of the New Jerusalem mainly manifests itself through pure geometric shapes. Through different visions, one can indicate the square/cube and the circle as the geometric shapes used for depicting the structure of the New Jerusalem. The proportion of the cube, being 1:1:1, and the circular shape by itself, is the geometric expressions of perfectness. Beside this, the building material being of precious stones and crystals reflects the idea of incorruptibility and everlasting spiritual powers governing the city. In such a way perfected form corresponds to the spiritual and ethical values which it embodies.

It seems that this principle reflects on the shape of monasteries, mirroring the divine scheme and the ideal vision of ethical purity by which one dwells in Heaven. They are not only metaphorically equalized with the spiritual perfectness of the Heavenly City, but also by ideas forming them as squares or circles. In that sense, in the monasteries placing the church building in the center of the complex, one can recognize the general disposition described particularly in visions of circularly shaped heavenly city. In these examples, the church building is equalized with the body of Christ, the sacrificial lamb, or the high altar, always represented as the central point in these descriptions. The choice of the shape for the general structure of the monastery, either square or circular, is probably reflection on the preferable ideal vision used as the precedence.

As shown in this short analysis, the link between the materialized structure of medieval monasteries, heavenly visions and descriptions of cities as ethical ideals is recognizable and established as a metaphorical interpretation of particular Christian virtues. In that process the equivalence between the building structure, particularly for dwelling, and the Christian virtue of humility, as one of the most important in this context, defines the perceptual quality of architecture and its spiritual content. Architectural frame becomes a stronghold for ethical norms which it mirrors. This way a dwelling structure can be equalized with the ethical structure of its inhabitants.

However, if we turn back to the beginning of our discussion, one can indicate a particular issue concerning the real influence of early Christian ethics on the process of transformation of existing ancient urban structures. It is very hard to imagine in which way the architectural mega structures, after their primary 
functions where abandoned, continued to exist in the urban matrix. We have texts informing us about the practice of transforming temples into Christian churches. However, what exactly happened with circuses, amphitheaters, baths and other monumental buildings, particularly after the proclamation of Theodosius, we cannot confidently say. Also, it is hardly to know was the proclamation, or was it not, implemented generally, in the entire empire, or only on the demands of a particular city and its inhabitants.

Archeological remains are informing us about the particular practice by which the new mediaeval buildings have been built into, or on the top of ancient structures. However, when this practice started, whether under theological influence or not, and was there a difference in the approach according to that in which part of the empire it took place, is a particular issue.

However, it seems that the razing of ancient urban structures had started before the barbarians began to demolish them entirely. It is uncertain what would have happened with the Roman cities if the process of raising their structures under the influence of the Christian new ways of life had continued uninterruptedly. Maybe the answer to this dilemma could be found through a more careful research of Byzantine cities and their continuous development and life.

Nevertheless, it appears that the ethical ideals discussed in this work had developed mainly through theological ideas regarding new forms of sacral buildings and of the life in particular communities. Its reflection on living in cities existing at the time is an issue of a high importance, enabling us to understand the beginning of one of the most intensive transformations in the process of development of urban and architectural structures, as well as the changes of their functions and of the notion of being a citizen and an inhabitant. 
Tertulian, "De spectaculis," in The Ante-Nicene Fathers, ed. Alexander Roberts and James Donaldson, Vol.3 (Buffalo: 1885), 79.

Ibid., 83.

Plato, "Critias," in The Dialogues of Plato, Vol.3 (London: 1875), 115c, 115d, 116b.

Plato, "Laws," in The Dialogues of Plato, Vol.5 (London: 1931), 779b; Vladimir Mako, Aesthetic Thoughts on Architecture-Middle Ages (Belgrade: 2011), 65.

Temple W., Plato and Christianity: Three Lectures (London: 1916), 32.

Seneca, Ad Lucilium epistulae morales, Vol.2 (London: 1962), 86; Vladimir Mako, Aesthetic Thoughts, 134-135.

John Chrysostom, "The Homilies on the Statues: to the People of Antioch," in Nicene and PostNicene Fathers of the Christian Church, Vol.9 (New York: 1889), 456.

Sulpitius Severus, "The Secret History," in A Select Library of Nicene and Post-Nicene Fathers of the Church, Vol.11 (New York: 1894), 113.

Chrysostom, "The Homilies on the Statues: to the People of Antioch,", 349.

Ibid., 455.

Gregory Nazianzen, "Select Orations," in A Select Library of Nicene and Post-Nicene Fathers of the Church, Vol.7 (New York: 1894), 415 - 416.

Ibid., 416.

Palladius, "The History of Holy Man," in The Book of Paradise, Vol.1 (London: 1904), 144 - 145.

Tertulian, "De spectaculis,", 91.

Chrysostom, "The Homilies on the Statues: to the People of Antioch,", 156.

Gregory, "Select Orations,", 239- 240.

John Cassian, "The Twel Book on the Institutes of the Coenobia and the Remedies for the Eight Principal Faults," in Nicene and Post-Nicene Fathers of the Christian Church, Vol.11 (New York: 1894), 438.

Cyril, "The Catechetical Lectures," in Nicene and Post-Nicene Fathers of the Christian Church, Vol.7 (New York: 1894), 11.

John Chrysostom, "Homilies on Ephesians: Homily X," in Nicene and Post-Nicene Fathers of the Christian Church, Vol.3, (Grand Kapids: 1956), 101.

"The Vision of Paul," in The Ante-Nicene Fathers: the writings of the fathers down to AD 325 , Vol.9 (New York: 1906), 157- 158.

An Irish Precursor of Dante: a Study on the Vision of Heaven and Hell Ascribed to the EightCentury Irish Saint Adamnan (London: 1908), 31.

Beda Venerabilis, Ecclesiastical History of England (London: 1894), 175.

Hugonis de S.Victore, Opera omnia, Tom 2 (Parisiis: 1880),629, 631, 681, 1087.

Ibid., 1131.

Константин Филозоф, „Житије деспота Стефана Лазаревића,“ in Cmaра српска књижевност, къ.11 (Београд: 1989), 59. 
An Irish Precursor of Dante: a Study on the Vision of Heaven and Hell Ascribed to the EightCentury Irish Saint Adamnan. London: Published by David Nutt, 1908.

Chrysostom, John. "The Homilies on the Statues: to the People of Antioch." In Nicene and PostNicene Fathers of the Christian Church, Vol.9. New York: The Christian Literature Company, 1889.

Chrysostom, John. "Homilies on Ephesians: Homily X." In Nicene and Post-Nicene Fathers of the Christian Church, Vol.3. Grand Kapids, Michigan: B. Eerdmans Publishing Co., 1956.

Cassian, John. "The Twel Book on the Institutes of the Coenobia and the Remedies for the Eight Principal Faults." In Nicene and Post-Nicene Fathers of the Christian Church, Vol.11. New York: The Christian Literature Co.- Parker \& Co., 1894.

De S.Victore, Hugonis. Opera omnia, Tom 2. Parisiis: Apud Garnier Fratres, 1880.

Mako, Vladimir. Aesthetic Thoughts on Architecture-Middle Ages. Belgrade: Faculty of Architecture University of Belgrade, 2011.

Nazianzen, Gregory. "Select Orations." In A Select Library of Nicene and Post-Nicene Fathers of the Church, Vol.7. New York: The Christian Literature Company - Parker \& Co., 1894.

Plato. "Critias." In The Dialogues of Plato, Vol.3. Oxford: At the Clarendon Press, 1875.

Plato. "Laws." In The Dialogues of Plato, Vol.5. London: Oxford University Press \& Humphry Milford, 1931.

Palladius. "The History of Holy Man.” In The Book of Paradise, Vol.1. London: Chatto \& Windus, 1904.

Seneca. "Ad Lucilium epistulae morales, Vol.2. London: William Heineman Ltd. \& Harvard University Press, 1962.

Severus, Sulpitius. "The Secret History." In A Select Library of Nicene and Post-Nicene Fathers of the Church, Vol.11. New York: The Christian Literature Company, 1894.

St. Cyril. "The Catechetical Lectures." In Nicene and Post-Nicene Fathers of the Christian Church, Vol.7. New York: The Christian Literature Co.- Parker \& Co., 1894.

Tertulian. "De spectaculi." In The Ante-Nicene Fathers, ed. Alexander Roberts \& James Donaldson, Vol.3. Buffalo, 1885.

Temple, William. Plato and Christianity: Three Lectures. London, 1916.

"The Vision of Paul." In The Ante-Nicene Fathers: the writings of the fathers down to AD 325, Vol.9. New York: Charles Scribner's Sons, 1906.

Venerabilis, Beda. Ecclesiastical History of England. London: George Bell \& Sons, 1894.

Филозоф, Константин. „Житије деспота Стефана Лазаревића.“ In Cтара српска књижевност, књ.11. Београд: Просвета, 1989. 


\section{ETIKA STANOVANJA: RANI HRIŠĆANSKI PRINCIPI GRADSKOG ŽIVOTA I URBANE TRANSFORMACIJE \\ Vladimir Mako}

Rad se fokusira na određeno pitanje u vezi etike koja se razvila u ranom hrišćanskom vremenu i njenog uticaja na proces transformacije rimskog urbanog života, navika, funkcije i arhitektonske prakse krajem petog veka i nakon toga.

Složenost ovog pitanja proizilazi iz činjenice da su rani hrišćanski monaški ideali, koji su se brzo razvili u prvim vekovima nove ere, značajno uticali na formiranje svakodnevnih životnih etičkih principa.

Shodno tome, ovi novi principi su promenili postojeće navike u stanovanju, posebno u oblasti javnog života, zahtevajući novi oblik ponašanja od hrišćanskih građana. Ovaj proces je uticao i na idealistički pogled na ono što koncept hrišćanskog grada može biti, i kako se novi oblik etičkog života odražava na nove urbane i arhitektonske strukture.

KLJUČNE REČI: ETIKA, ESTETIKA, GRADSKI ŽIVOT, URBANA TRANSFORMACIJA

\section{UMETNOST, MODERNOST I SKEPTICIZAM \\ Nikola Dedić}

Ovaj rad se bavi problemom odnosa umetnosti i modernosti - naša osnovna teza je da se umetnik u eri modernosti bavi problemom privatnosti. Pojam privatnosti se koristi u Vitgenštajnovom smislu, kao analogija njegovoj teoretizaciji fantazije privatnog jezika. Njegov koncept privatnog jezika je opis povlačenja običnog jezika iz procesa međudruštvenih odnosa i njegove svakodnevne upotrebe; na taj način, fantazija privatnog jezika je vrsta skepticizma. S obzirom na to da je pojam epistemološkog skepticizma povezan sa idejom modernosti (Dekartov, Hjumov, Lokov moderni skeptični predmet), glavni problem za savremenog umetnika je kako da prevaziđe stanje radikalnog skepticizma, odnosno uslov koji Stenli Kavel u Vitgenštajnovom smislu naziva 'metafizička izolacija'.

KLJUČNE REČI: UMETNOST, MODERNOST, SKEPTICIZAM, PRIVATNI JEZIK, OBIČAN JEZIK, LUDVIG VITGENŠTAJN, STENLI KAVEL

OD TRANSCENDENTALNOG IDEALIZMA DO TRANSCENDENTALNOG

EMPIRIZMA I ŠIRE: KANT, DELEZ I RAVNA ONTOLOGIJA UMETNOSTI Andrija Filipović

U ovom radu ću pokazati da pokret od Kantovog transcendentalnog idealizma do Žil Delezovog transcendentalnog empirizma, a zatim do novih materializma i spekulativnih realizma je ono što nam omogućava da razgovaramo o direktnom i ne-posredovanom pristupu stvari u sebi (ili njenom raspadanju). Drugim rečima, to je promena od uslova mogućeg iskustva do uslova realnog iskustva koja su omogućila trenutne filozofske i teorijske diskurse materializma i realizma. Ono što je od posebnog interesa za potrebe ovog rada je kako je promena od uslova mogućeg do stvarnog iskustva povezana sa trenutnom konceptualizacijom umetničkih praksi. Tačnije, ja ću pokazati kako se ontologija umetnosti promenila, ili barem da se možda čini da postoji mogućnost premeštanja paradigme različitih estetika i ontologija umetnosti, gde je ravna ontologija jedna od njih, sa pojavom novih materializma i spekulativnih realizma koji su omogućeni promenom u uslovima realnog iskustva.

KLJUČNE REČI: TRANSCENDENTALNI IDEALIZAM, TRANSCENDENTALNI EMPIRIZAM, RAVNA ONTOLOGIJA,

UMETNOST, KANT, DELEZ

IMPLIKACIJE VATIMOVOG VERWINDUNG-A MODERNIZMA

\section{U ARHITEKTONSKOJ TEORIJI}

\section{Vladimir Stevanović}

U postmodernom dobu, osim novog pristupa arhitektonskoj praksi, dešavaju se značajne promene u bavljenju arhitektonskim pisanjem i to zahvaljujući uplivu postmoderne transdisciplinarne teorije u arhitektonski diskurs. Arhitektonski teoretičari, kritičari i istoričari rado koriste doprinos 
filozofije, političkih nauka, sociologije, teorije umetnosti i književne kritike na polju kategorizacije i interpretacije postmodernih arhitektonskih stilova ili tendencija. Kako formalno-likovni aspekti prestaju da budu ekskluzivni faktor koji konstituiše stil ili tendenciju, dolazi do implementacije tema i paradigmi iz raznih postmodernih teorija, što dovodi do fenomena prevođenja teorije za arhitektonske potrebe. U većini slučajeva teorijski nazori služe kao pokriće u skladu sa kojim teoretičari arhitekture formulišu autorske poetike određenih arhitekata, proglašavaju poželjne modele recepcije njihovih arhitektonskih dela, i formiraju ukupne stavove prema disciplinarnom i društveno-istorijskom kontekstu. Međutim, postaje interesantno kada ista arhitektonska dela jednog ili više arhitekata bivaju na različite načine interpretirana od strane različitih arhitektonskih teoretičara. U tom smislu, rad sagledava ove premise na konkretnom primeru (1) u kome praksu čini Katalonska arhitektura osamdesetih, (2) u kome se ukrštaju ideje de Solà-Moralesa, Rosija i Fremptona, (3) a teorijski obrazac na koji se može fokusirati je Vatimov filozofski koncept Verwindung-a modernizma.

KLJUČNE REČI: VERWINDUNG, SLABA MISAO, MODERNIZAM, POSTMODERNIZAM, FUNDAMENTALIZAM, FRAGMENTARNOST

PITANJE PREDSTAVLJANJA I IDENTITETA IZMEĐU GLOBALIZMA I LOKALIZMA: SLUČAJ PAVILJONA HONG KONGA NA VENECIJANSKOM BIJENALU

\section{Eva Kit Vah Man}

Ovaj rad uzima umetničku instalaciju Li Kita izloženu u paviljonu Hong Konga na Bijenalu u Veneciji 2013. godine, kao studiju slučaja da ilustruje načine na koje dela nude i pomažu sačinjavanje izazvanog Hong Konga i subverziju agresivne i moćno rastuću Kine. Za razliku od 'očigledne' društvene kritike i 'grandioznog' izgleda umetničkih dela izloženih u kineskom paviljonu, Li Kitova umetnička instalacija - "impresionistička kuća” - u Hong Kongovom paviljonu ne samo da izgleda apstraktno, već i svetovno i čak i trivijalno. Pošto je umetnik bio izabran od strane organizatora bez učešća javnosti, ovo je generisalo žestoku javnu raspravu o reprezentativnosti 'Hongkongnosti' ove instalacije. Moja tvrdnja je da je ono što se čini trivijalnim i običnim u Lijevom radu predstavljeno da konstitutiše, a ne prikaže, umetnost nove generacije Hong Konga. To takođe može biti taktika manevarisanja političkim identitetom koji je nametnula Kina Hong Kongu svojim sveprisutnim i pritiskajućim prisustvom. Umetnost Hong Konga ima potencijal da se udalji ili da sumnja u velike narative Kine, da parafraziram reči istoričara umetnosti Dejvida Klarka (1997). Verujem da je motiv međunarodne konferencije "Hong Kong kao metod" decembra 2014. na Univerzitetu u Hong Kongu bio da upotrebom očekivanog destabilizuje i ospori hongkonški "zdravo-za-gotovo" politički identitet i na taj način promoviše raznolikosti i međuazijsku kulturnu dinamiku.

KLJUČNE REČI: UMETNOST INSTALACIJA, HONGKONGNOST, KINESKOST, POLITIKA IDENTITETA, GLOBALIZAM

SAVREMENA KINESKA UMETNOST:

MAOVO NASLEĐE I DANTOOVA DEFINICIJA

Mary Bittner Wiseman

U ovom radu pokušala sam da izvedem tri stvari. Kao prvo, da identifikujem nekoliko tema $\mathrm{u}$ savremenoj kineskoj umetnosti kroz koje pokazuje svoju suštinski socijalna prirodu i svoj robustan materijalizam, karakteristike kojih nema često u zapadnoj umetnosti. Drugo, da ukažem da način na koji je savremena umetnost u Kini postmoderna jete način na koji je i zapadna umetnost, i da potkrepim tvrdnju da koliko god da su teme i nedavna istorija ove umetnosti drugačije od zapadnog pandana, ova umetnost zadovoljava definiciju umetnosti koju je konstruisao Artur Danto, a to je ona koja na fino zaokružuje i širinu i dubinu koncepta umetnosti. Konačno, u poslednjem delu, predstaviću rad jedne žene-umetnika koji se razlikuje od većine skorašnjih kineskih radova i tipičnih radova zapadne umetnost. On se pozicionira na marginama onoga što je umetnost u Kini i što Dantoova definicija obuhvata, istovremeno sugerišući srž umetničke prakse i jedan od načina biti žena. 